\title{
BMJ Open Association of socioeconomic factors and the risk for unintentional injuries among children in Japan: a cross- sectional study
}

\author{
Nobuhiro Sato, ${ }^{1}$ Yusuke Hagiwara, ${ }^{2}$ Junta Ishikawa, ${ }^{1}$ Kohei Akazawa ${ }^{1}$
}

To cite: Sato N, Hagiwara Y, Ishikawa J, et al. Association of socioeconomic factors and the risk for unintentional injuries among children in Japan: a cross-sectional study. BMJ Open 2018:8:e021621. doi:10.1136/ bmjopen-2018-021621

- Prepublication history and additional material for this paper are available online. To view these files, please visit the journal online (http://dx.doi. org/10.1136/bmjopen-2018021621).

Received 11 January 2018

Revised 23 July 2018

Accepted 26 July 2018

\section{Check for updates}

(C) Author(s) (or their employer(s)) 2018. Re-use permitted under CC BY-NC. No commercial re-use. See rights and permissions. Published by BMJ.

${ }^{1}$ Department of Medical Informatics and Statistics, Niigata University Graduate School of Medicine, Niigata, Japan

${ }^{2}$ Department of Pediatric Emergency and Critical Care Medicine, Tokyo Metropolitan Children's Medical Center, Tokyo, Japan

Correspondence to Dr Nobuhiro Sato;

s_nobuhiro@hosp.niigata. niigata.jp

\section{ABSTRACT}

Objectives While Japan has socioeconomic issues, such as income inequality, little is known about the association between socioeconomic factors and the risk of unintentional childhood injuries. The purpose of the study was to evaluate the influence of socioeconomic factors on the risk for unintentional injuries among preschool children in Japan.

Design Cross-sectional study using data from a webbased questionnaire survey.

Setting Japan (January 2015).

Participants 1000 households with preschool children under 6 years of age.

Outcome measures Multivariate logistic regression was performed to analyse the influence of socioeconomic factors on the incidence of unintentional injuries. Results Overall, 976 households were eligible for the analysis, with 201 households reporting unintentional injuries. The incidence rates for unintentional injury were estimated to be constant across all strata constructed using combinations of socioeconomic factors. The multivariate logistic regression analysis showed no significant differences in socioeconomic factors between households that reported unintentional injuries and those that did not.

Conclusion The findings of our study demonstrated that unintentional injuries among preschool children occurred at approximately fixed rates, independent of socioeconomic factors. Accordingly, prevention strategies for unintentional injuries that concern socioeconomic disadvantages should be avoided in Japan.

\section{INTRODUCTION}

Unintentional injuries are a leading cause of death among children of all ages. ${ }^{1-4}$ The term 'unintentional injury' in this context is defined as an injury that is not inflicted deliberately; the injury may have been caused by a fall, poisoning, drowning, burns or traffic-related accidents. Globally, unintentional injuries accounted for $15.4 \%$ of approximately 2.6 million deaths recorded for children aged 1 to 14 years in $2013 .{ }^{1}$ In particular, children aged 1 to 4 years demonstrate the highest all-cause and cause-specific mortality
Strengths and limitations of this study

A nationwide questionnaire survey administered in Japan.

- 1000 households with a population distribution similar to that in the national census were included.

- Confounders by unmeasured factors, such as physical disabilities in children, are study limitations.

rates due to unintentional injuries. ${ }^{1}$ The risks for unintentional injuries among children are mainly defined by individual factors (behaviours and attributes), the presence or absence of supervision and safety equipment and vehicle safety. ${ }^{5}$ Moreover, the risks can be influenced by socioeconomic factors, including family income, parental education, single parenting, maternal age, older siblings and type of housing. ${ }^{6-13}$ In fact, Laursen et al reported that children with young mothers and mothers with only primary school education were at higher risk for most types of injuries than other children in Denmark. ${ }^{10}$

Similarly, in Japan, unintentional injuries have been a major cause of death among children aged $\geq 1$ year since $1960 .{ }^{1415}$ Furthermore, several socioeconomic issues exist in Japan. For example, Japan is ranked fourth highest for income inequality across the Organisation for Economic Cooperation and Development member countries. ${ }^{16}$ The relative poverty rate for households with children was $12.9 \%$ in $2015 .{ }^{17}$ A previous study revealed the association between socioeconomic inequality and the risk for infant abuse in Japan. ${ }^{18}$ However, only a few studies have examined the relationship between socioeconomic status and unintentional injury among children in Japan thus far.

The purpose of this study was to evaluate the influence of socioeconomic factors on 
the risk for unintentional injuries among children in Japan via a nationwide questionnaire survey.

\section{METHODS}

\section{Study design and participants}

This study involved a web-based questionnaire survey. The participants were selected in January 2015 from a database of 1370000 candidates compiled by a private Japanese company specialising in questionnaire-based research. We extracted data for 1000 households with preschool children under 6years of age. All participants lived in Japan. Region was used as a variable for stratified random sampling. Hence, the region-wise distribution of our sample was almost identical to that of the general population in Japan. All respondents completed the questionnaire on a website developed specially for this study by the survey company. Exclusion criteria included

Table 1 Characteristics of 976 households with preschool children under 6 years old

\begin{tabular}{|c|c|c|}
\hline Factors & $\mathrm{n}=976$ & $\%$ \\
\hline \multicolumn{3}{|l|}{ Respondent } \\
\hline Mother & 569 & 58.3 \\
\hline Father & 407 & 41.7 \\
\hline \multicolumn{3}{|l|}{ Region } \\
\hline Urban area & 678 & 69.5 \\
\hline Others & 298 & 30.5 \\
\hline \multicolumn{3}{|l|}{ Family type } \\
\hline Two parents & 936 & 95.9 \\
\hline Single parent & 40 & 4.1 \\
\hline \multicolumn{3}{|c|}{ Number of children } \\
\hline 1 & 375 & 38.4 \\
\hline 2 & 447 & 45.8 \\
\hline$\geq 3$ & 154 & 15.8 \\
\hline \multicolumn{3}{|c|}{ Living with grandparent } \\
\hline Yes & 389 & 39.9 \\
\hline No & 587 & 60.1 \\
\hline \multicolumn{3}{|c|}{ Use of sitter, kindergarten or nursery school } \\
\hline Yes & 197 & 20.2 \\
\hline No & 779 & 79.8 \\
\hline \multicolumn{3}{|l|}{ Type of housing } \\
\hline House & 516 & 52.9 \\
\hline Apartment & 460 & 47.1 \\
\hline \multicolumn{3}{|l|}{ Annual income } \\
\hline$<3$ million & 117 & 12.0 \\
\hline 3-5 million & 366 & 37.5 \\
\hline$>5$ million & 493 & 50.5 \\
\hline \multicolumn{3}{|c|}{ Unintentional injury } \\
\hline Yes & 201 & 20.6 \\
\hline No & 775 & 79.4 \\
\hline
\end{tabular}

not living with parents; missing information regarding parent education and type of housing; and children being cared for by people other than the parents, grandparents, kindergarten teachers and nursery teachers during the daytime. An urban area was defined as an area with $>15$ million residents. Returning the questionnaire was taken as agreement to participate in the study and informed consent was obtained from all participants.

\section{Measures}

The questionnaire included 20 questions about basic and socioeconomic characteristics and 17 questions concerning unintentional injuries. The following socioeconomic factors were used for evaluation: father's age; mother's age; living area; number of siblings; highest education levels of parents; annual income of parents; type of housing; parents' employment status; living with grandparents; primary caregiver during the daytime and at night; use of a sitter, kindergarten or nursery school; and history of injuries. Parents were divided into three groups according to the mean age of mothers (30.7 years old) at the birth of the first child in Japan: $\leq 29$ years, $30-39$ years and $\geq 40$ years. ${ }^{15}$ Highest education level was classified as junior high school or high school, business

Table 2 Distribution of 201 unintentionally injured children by injury-descriptive factors

\begin{tabular}{lrr}
\hline Factors & $\mathbf{n = 2 0 1}$ & $\%$ \\
\hline Injury mechanism (multiple answers) & \\
\hline Fall & 117 & 58.2 \\
\hline Burn & 47 & 23.4 \\
Poisoning/Aspiration & 12 & 6.0 \\
Drowning & 6 & 3.0 \\
Traffic injury & 7 & 3.5 \\
Others & 12 & 6.0 \\
\hline
\end{tabular}

\section{Gender of child}

$\begin{array}{lrr}\text { Male } & 119 & 59.2 \\ \quad \text { Female } & 82 & 40.8 \\ \text { Time of injury } & & \\ \quad \text { Daytime on a weekday } & 106 & 52.7 \\ \quad \text { Night-time on a weekday } & 64 & 31.8 \\ \quad \text { Holiday } & 31 & 15.4 \\ \text { Place of injury } & & \\ \quad \text { Home } & 188 & 93.5 \\ \text { Outdoor } & 13 & 6.5\end{array}$

Witnessed by caregivers

\begin{tabular}{lrr} 
Yes & 129 & 64.2 \\
No & 72 & 35.8 \\
Management after injury & & \\
Visit hospital & 112 & 55.7 \\
Observation at home & 88 & 43.8 \\
Others & 1 & 0.5 \\
\hline
\end{tabular}




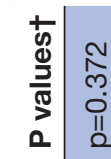

II

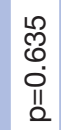

9
$\substack{0 \\ 0 \\ 0 \\ 11 \\ 0}$

$\stackrel{8}{\circ}$

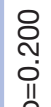

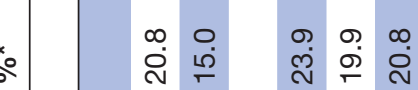

$\circ$

这

胥

ณ̊ำ

$\stackrel{ }{N} \stackrel{\circ}{=} 8$

묘

$\stackrel{\infty}{\infty} \infty$

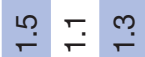

$\stackrel{+}{\leftarrow}$

ป⿱艹

$\stackrel{m}{\circ}$ 웅

$\stackrel{\infty}{\stackrel{0}{\leftarrow}}$

잉

$\sim \infty \sim$

*

$$
\text { ำ }
$$

영 옹

品范

동

停 焉

竞

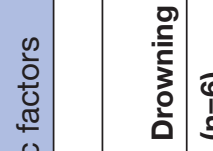

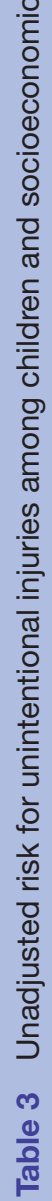

$\stackrel{*}{\circ}$

के :

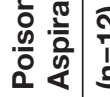

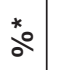

空

?롤

*

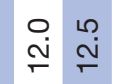

ம $\stackrel{\infty}{\sim}$

ก ส

$\stackrel{2}{ก}$

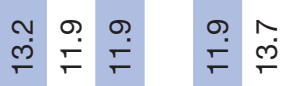

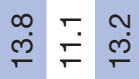

느 웡

○员员

m

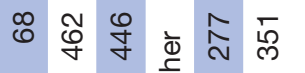

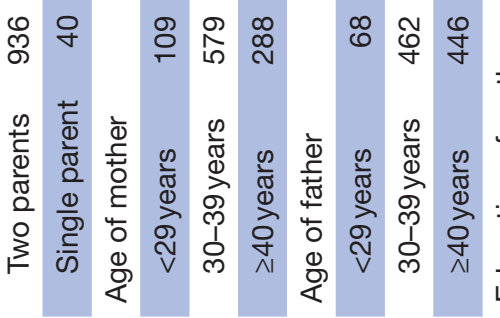

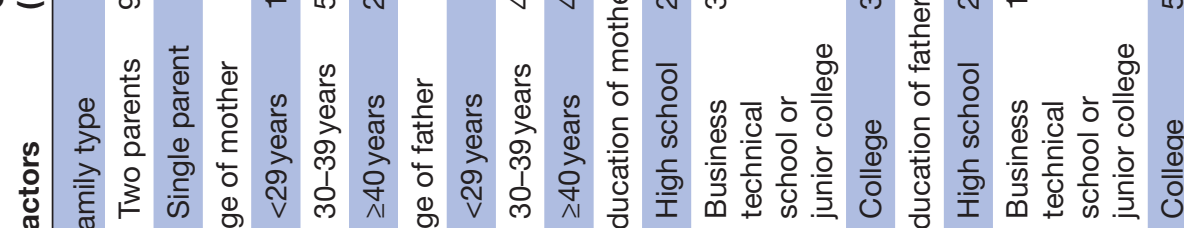

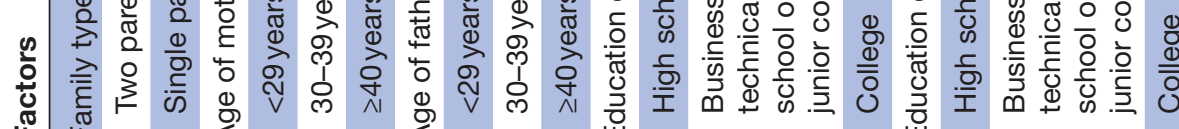

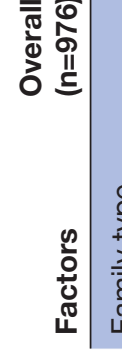

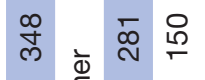

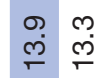

이 요 


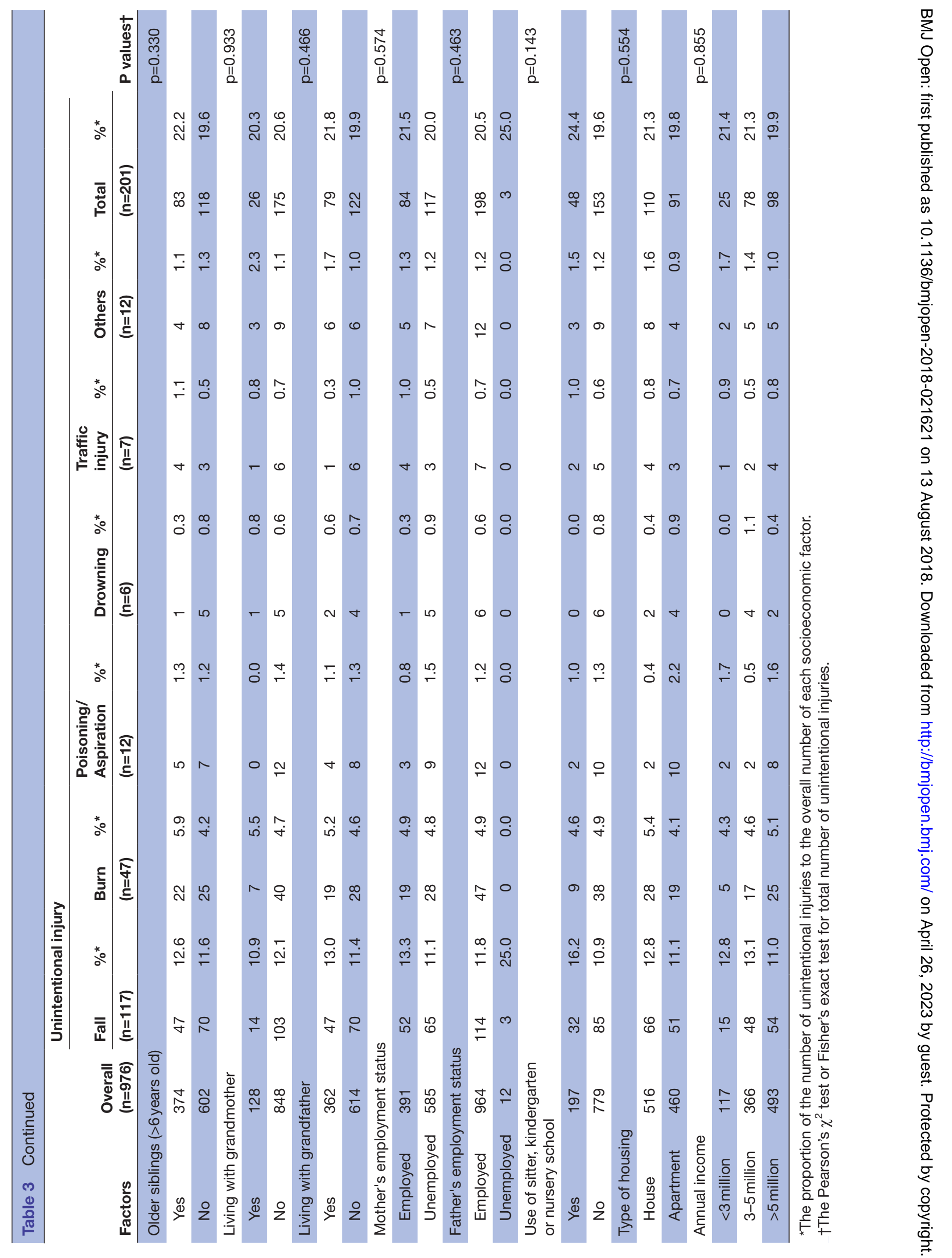


Table 4 Time of unintentional injuries among children and socioeconomic factors

\begin{tabular}{|c|c|c|c|c|c|c|c|c|c|}
\hline \multirow[b]{3}{*}{ Factors } & \multirow{3}{*}{$\begin{array}{l}\text { Overall } \\
(n=976)\end{array}$} & \multicolumn{8}{|c|}{ Unintentional injury } \\
\hline & & $\begin{array}{l}\text { Daytime on a } \\
\text { weekday }\end{array}$ & $\% *$ & $\begin{array}{l}\text { Night- } \\
\text { time on a } \\
\text { weekday }\end{array}$ & $\%^{*}$ & Holiday & $\%^{*}$ & Total & $\%^{*}$ \\
\hline & & $(n=106)$ & & $(n=64)$ & & $(n=31)$ & & $(n=201)$ & \\
\hline \multicolumn{10}{|l|}{ Family type } \\
\hline Two parents & 936 & 102 & 10.9 & 62 & 6.6 & 31 & 3.3 & 195 & 20.8 \\
\hline Single parent & 40 & 4 & 10.0 & 2 & 5.0 & 0 & 0.0 & 6 & 15.0 \\
\hline \multicolumn{10}{|l|}{ Age of mother } \\
\hline$<29$ years & 109 & 14 & 12.8 & 8 & 7.3 & 4 & 3.7 & 26 & 23.9 \\
\hline 30-39years & 579 & 65 & 11.2 & 32 & 5.5 & 18 & 3.1 & 115 & 19.9 \\
\hline$\geq 40$ years & 288 & 27 & 9.4 & 24 & 8.3 & 9 & 3.1 & 60 & 20.8 \\
\hline \multicolumn{10}{|l|}{ Age of father } \\
\hline$<29$ years & 68 & 9 & 13.2 & 4 & 5.9 & 1 & 1.5 & 14 & 20.6 \\
\hline $30-39$ years & 462 & 52 & 11.3 & 26 & 5.6 & 15 & 3.2 & 93 & 20.1 \\
\hline$\geq 40$ years & 446 & 45 & 10.1 & 34 & 7.6 & 15 & 3.4 & 94 & 21.1 \\
\hline \multicolumn{10}{|l|}{ Education of mother } \\
\hline High school & 277 & 29 & 10.5 & 20 & 7.2 & 9 & 3.2 & 58 & 20.9 \\
\hline $\begin{array}{l}\text { Business technical } \\
\text { school or junior college }\end{array}$ & 351 & 43 & 12.3 & 25 & 7.1 & 14 & 4.0 & 82 & 23.4 \\
\hline College & 348 & 34 & 9.8 & 19 & 5.5 & 8 & 2.3 & 61 & 17.5 \\
\hline \multicolumn{10}{|l|}{ Education of father } \\
\hline High school & 281 & 34 & 12.1 & 22 & 7.8 & 12 & 4.3 & 68 & 24.2 \\
\hline $\begin{array}{l}\text { Business technical } \\
\text { school or junior college }\end{array}$ & 150 & 19 & 12.7 & 8 & 5.3 & 3 & 2.0 & 30 & 20.0 \\
\hline College & 545 & 53 & 9.7 & 34 & 6.2 & 16 & 2.9 & 103 & 18.9 \\
\hline \multicolumn{10}{|l|}{ Number of children } \\
\hline 1 & 375 & 37 & 9.9 & 19 & 5.1 & 9 & 2.4 & 65 & 17.3 \\
\hline 2 & 447 & 50 & 11.2 & 34 & 7.6 & 17 & 3.8 & 101 & 22.6 \\
\hline$\geq 3$ & 154 & 19 & 12.3 & 11 & 7.1 & 5 & 3.2 & 35 & 22.7 \\
\hline \multicolumn{10}{|l|}{ Infant (<1 year old $)$} \\
\hline Yes & 170 & 23 & 13.5 & 7 & 4.1 & 1 & 0.6 & 31 & 18.2 \\
\hline No & 806 & 83 & 10.3 & 57 & 7.1 & 30 & 3.7 & 170 & 21.1 \\
\hline \multicolumn{10}{|l|}{ Older siblings (>6 years old) } \\
\hline Yes & 374 & 43 & 11.5 & 24 & 6.4 & 16 & 4.3 & 83 & 22.2 \\
\hline No & 602 & 63 & 10.5 & 40 & 6.6 & 15 & 2.5 & 118 & 19.6 \\
\hline \multicolumn{10}{|l|}{ Living with grandmother } \\
\hline Yes & 128 & 13 & 10.2 & 7 & 5.5 & 6 & 4.7 & 26 & 20.3 \\
\hline No & 848 & 93 & 11.0 & 57 & 6.7 & 25 & 2.9 & 175 & 20.6 \\
\hline \multicolumn{10}{|l|}{ Living with grandfather } \\
\hline Yes & 362 & 44 & 12.2 & 26 & 7.2 & 9 & 2.5 & 79 & 21.8 \\
\hline No & 614 & 62 & 10.1 & 38 & 6.2 & 22 & 3.6 & 122 & 19.9 \\
\hline \multicolumn{10}{|c|}{ Mother's employment status } \\
\hline Employed & 391 & 35 & 9.0 & 33 & 8.4 & 16 & 4.1 & 84 & 21.5 \\
\hline Unemployed & 585 & 71 & 12.1 & 31 & 5.3 & 15 & 2.6 & 117 & 20.0 \\
\hline \multicolumn{10}{|l|}{ Father's employment status } \\
\hline Employed & 964 & 104 & 10.8 & 63 & 6.5 & 31 & 3.2 & 198 & 20.5 \\
\hline Unemployed & 12 & 2 & 16.7 & 1 & 8.3 & 0 & 0.0 & 3 & 25.0 \\
\hline
\end{tabular}


Table 4 Continued

\begin{tabular}{|c|c|c|c|c|c|c|c|c|c|}
\hline \multirow[b]{3}{*}{ Factors } & \multirow{3}{*}{$\begin{array}{l}\text { Overall } \\
(n=976)\end{array}$} & \multicolumn{8}{|c|}{ Unintentional injury } \\
\hline & & $\begin{array}{l}\text { Daytime on a } \\
\text { weekday }\end{array}$ & \%* & $\begin{array}{l}\text { Night- } \\
\text { time on a } \\
\text { weekday }\end{array}$ & \%* & Holiday & $\%{ }^{*}$ & Total & $\% *$ \\
\hline & & $(n=106)$ & & $(n=64)$ & & $(n=31)$ & & $(n=201)$ & \\
\hline \multicolumn{10}{|c|}{$\begin{array}{l}\text { Use of sitter, kindergarten or nursery } \\
\text { school }\end{array}$} \\
\hline No & 779 & 90 & 11.6 & 43 & 5.5 & 20 & 2.6 & 153 & 19.6 \\
\hline \multicolumn{10}{|c|}{ Type of housing } \\
\hline House & 516 & 59 & 11.4 & 34 & 6.6 & 17 & 3.3 & 110 & 21.3 \\
\hline Apartment & 460 & 47 & 10.2 & 30 & 6.5 & 14 & 3.0 & 91 & 19.8 \\
\hline \multicolumn{10}{|c|}{ Annual income } \\
\hline
\end{tabular}

*The proportion of the number of unintentional injuries to the overall number of each socioeconomic factor.

technical school or junior college and college. Annual income was classified as $<3$ million yen, $3-5$ million yen and $\geq 5$ million yen, based on the average income in Japan (median 4.28 million yen). ${ }^{17}$ Type of housing was divided into house and apartment house categories. Injury was defined as physical damage that was fatal or caused after-effects. We included the following types of injuries: all injuries, such as falls from stairs or a balcony; burns from hot liquids, hot surfaces or fire; accidental poisoning; foreign body aspiration or suffocation; drowning; and traffic injuries. ${ }^{10}$ The information collected about unintentional injuries included gender of child, time, place of injury, witnessed by others or not and management after injury. The injury mechanism was defined as the injury that the respondent considered to be the most severe when the child experienced multiple unintentional injuries.

\section{Statistical analysis}

The sample size calculation was performed on the basis of a statistical power of $80 \%$, two-sided $\mathrm{p}$ value of 0.05 , an event rate of $25 \%$ and a relative risk of socioeconomic disadvantage of 1.2, obtained from previous studies. ${ }^{810} 19$

Continuous data with skewed distributions are shown as medians and IQRs, and categorical data as proportions. The Pearson's $\chi^{2}$ test or Fisher's exact test was used to explore the significance of differences between households reporting unintentional injuries and those that did not report any injuries.

Multiple logistic regression analysis was used to estimate the ORs and 95\% CIs after controlling simultaneously for potential confounders. We used unintentional injury as the dependent variable. We included 15 significant risk factors in the analysis (family type, age of parents, education of parents, number of children, presence of infant or older siblings, living with grandparent, parents' employment status, use of sitter, kindergarten or nursery school, type of housing and annual income). All statistical tests were two-sided. A p value less than 0.05 was considered statistically significant. Data analysis was performed using SPSS, V.23.0 (IBM Corporation, Armonk, New York, USA).

\section{Patient and public involvement}

Patients and public were not involved in the design of the study.

\section{RESULTS}

\section{Characteristics of the study population}

Of the 1000 households that participated in this study, 24 families were excluded because of missing data regarding the parents' education $(n=2)$, type of housing $(n=17)$ and primary caregivers apart from parents, grandparents, kindergarten teachers and nursery school teachers during the daytime $(n=5)$. Table 1 shows the basic characteristics of the 976 households that were included in the study. The median age of the respondents was 38 years (IQR 33-42years). In total, 201 households reported unintentional injuries among children. Table 2 presents the distribution of the 201 unintentionally injured children according to injury-descriptive variables. The most frequently observed mechanism of injury was falls (58.2\%), followed by burns $(23.4 \%)$, poisoning/aspiration $(6.0 \%)$, drowning $(3.0 \%)$, traffic injury $(3.5 \%)$ and others $(6.0 \%)$.

Risk factors for unintentional injury among preschool children in Japan

Table 3 shows the incidence rates of 15 socioeconomic factors. The incidence of unintentional injury was estimated at approximately $21 \%$ with or without the presence of socioeconomic disadvantage. The risk for unintentional 
Table 5 Management after unintentional injuries among children and socioeconomic factors

\begin{tabular}{|c|c|c|c|c|c|c|c|c|c|}
\hline \multirow[b]{3}{*}{ Factors } & \multirow{3}{*}{$\begin{array}{l}\text { Overall } \\
(\mathrm{n}=976)\end{array}$} & \multicolumn{8}{|c|}{ Unintentional injury } \\
\hline & & $\begin{array}{l}\text { Visit } \\
\text { hospital }\end{array}$ & $\%^{*}$ & $\begin{array}{l}\text { Observation } \\
\text { at home }\end{array}$ & $\%^{*}$ & Others & $\%^{*}$ & Total & $\%^{*}$ \\
\hline & & $(n=112)$ & & $(n=88)$ & & $(n=1)$ & & $(n=201)$ & \\
\hline \multicolumn{10}{|l|}{ Family type } \\
\hline Two parents & 936 & 109 & 11.6 & 85 & 9.1 & 1 & 0.1 & 195 & 20.8 \\
\hline Single parent & 40 & 3 & 7.5 & 3 & 7.5 & 0 & 0.0 & 6 & 15.0 \\
\hline \multicolumn{10}{|l|}{ Age of mother } \\
\hline$<29$ years & 109 & 8 & 7.3 & 18 & 16.5 & 0 & 0.0 & 26 & 23.9 \\
\hline 30-39years & 579 & 63 & 10.9 & 52 & 9.0 & 0 & 0.0 & 115 & 19.9 \\
\hline$\geq 40$ years & 288 & 41 & 14.2 & 18 & 6.3 & 1 & 0.3 & 60 & 20.8 \\
\hline \multicolumn{10}{|l|}{ Age of father } \\
\hline$<29$ years & 68 & 5 & 7.4 & 9 & 13.2 & 0 & 0.0 & 14 & 20.6 \\
\hline 30-39years & 462 & 51 & 11.0 & 42 & 9.1 & 0 & 0.0 & 93 & 20.1 \\
\hline$\geq 40$ years & 446 & 56 & 12.6 & 37 & 8.3 & 1 & 0.2 & 94 & 21.1 \\
\hline \multicolumn{10}{|l|}{ Education of mother } \\
\hline High school & 277 & 27 & 9.7 & 30 & 10.8 & 0 & 0.0 & 58 & 20.9 \\
\hline $\begin{array}{l}\text { Business technical school } \\
\text { or junior college }\end{array}$ & 351 & 53 & 15.1 & 29 & 8.3 & 0 & 0.0 & 82 & 23.4 \\
\hline College & 348 & 32 & 9.2 & 29 & 8.3 & 1 & 0.3 & 61 & 17.5 \\
\hline \multicolumn{10}{|l|}{ Education of father } \\
\hline High school & 281 & 39 & 13.9 & 28 & 10.0 & 1 & 0.4 & 68 & 24.2 \\
\hline $\begin{array}{l}\text { Business technical school } \\
\text { or junior college }\end{array}$ & 150 & 19 & 12.7 & 11 & 7.3 & 0 & 0.0 & 30 & 20.0 \\
\hline College & 545 & 54 & 9.9 & 49 & 9.0 & 0 & 0.0 & 103 & 18.9 \\
\hline \multicolumn{10}{|l|}{ Number of children } \\
\hline 1 & 375 & 26 & 6.9 & 38 & 10.1 & 1 & 0.3 & 65 & 17.3 \\
\hline 2 & 447 & 61 & 13.6 & 40 & 8.9 & 0 & 0.0 & 101 & 22.6 \\
\hline$\geq 3$ & 154 & 25 & 16.2 & 10 & 6.5 & 0 & 0.0 & 35 & 22.7 \\
\hline \multicolumn{10}{|l|}{ Infant (<1 year old) } \\
\hline Yes & 170 & 13 & 7.6 & 18 & 10.6 & 0 & 0.0 & 31 & 18.2 \\
\hline No & 806 & 99 & 12.3 & 70 & 8.7 & 1 & 0.1 & 170 & 21.1 \\
\hline \multicolumn{10}{|l|}{ Older siblings (>6 years old) } \\
\hline Yes & 374 & 55 & 14.7 & 28 & 7.5 & 0 & 0.0 & 83 & 22.2 \\
\hline No & 602 & 57 & 9.5 & 60 & 10.0 & 1 & 0.2 & 118 & 19.6 \\
\hline \multicolumn{10}{|l|}{ Living with grandmother } \\
\hline Yes & 128 & 13 & 10.2 & 13 & 10.2 & 0 & 0.0 & 26 & 20.3 \\
\hline No & 848 & 99 & 11.7 & 75 & 8.8 & 1 & 0.1 & 175 & 20.6 \\
\hline \multicolumn{10}{|l|}{ Living with grandfather } \\
\hline Yes & 362 & 44 & 12.2 & 35 & 9.7 & 0 & 0.0 & 79 & 21.8 \\
\hline No & 614 & 68 & 11.1 & 53 & 8.6 & 1 & 0.2 & 122 & 19.9 \\
\hline \multicolumn{10}{|l|}{ Mother's employment status } \\
\hline Employed & 391 & 53 & 13.6 & 31 & 7.9 & 0 & 0.0 & 84 & 21.5 \\
\hline Unemployed & 585 & 59 & 10.1 & 57 & 9.7 & 1 & 0.2 & 117 & 20.0 \\
\hline \multicolumn{10}{|l|}{ Father's employment status } \\
\hline Employed & 964 & 110 & 11.4 & 87 & 9.0 & 1 & 0.1 & 198 & 20.5 \\
\hline Unemployed & 12 & 2 & 16.7 & 1 & 8.3 & 0 & 0.0 & 3 & 25.0 \\
\hline
\end{tabular}


Table 5 Continued

\begin{tabular}{|c|c|c|c|c|c|c|c|c|c|}
\hline \multirow[b]{3}{*}{ Factors } & \multirow{3}{*}{$\begin{array}{l}\text { Overall } \\
(n=976)\end{array}$} & \multicolumn{8}{|c|}{ Unintentional injury } \\
\hline & & $\begin{array}{l}\text { Visit } \\
\text { hospital }\end{array}$ & $\% *$ & $\begin{array}{l}\text { Observation } \\
\text { at home }\end{array}$ & $\%^{*}$ & Others & $\%^{*}$ & Total & $\%^{*}$ \\
\hline & & $(n=112)$ & & $(n=88)$ & & $(n=1)$ & & $(n=201)$ & \\
\hline \multicolumn{10}{|c|}{ Use of sitter, kindergarten or nursery school } \\
\hline Yes & 197 & 32 & 16.2 & 16 & 8.1 & 0 & 0.0 & 48 & 24.4 \\
\hline No & 779 & 80 & 10.3 & 72 & 9.2 & 1 & 0.1 & 153 & 19.6 \\
\hline \multicolumn{10}{|c|}{ Type of housing } \\
\hline House & 516 & 73 & 14.1 & 37 & 7.2 & 0 & 0.0 & 110 & 21.3 \\
\hline Apartment & 460 & 39 & 8.5 & 51 & 11.1 & 1 & 0.2 & 91 & 19.8 \\
\hline \multicolumn{10}{|c|}{ Annual income } \\
\hline$<3$ million & 117 & 14 & 12.0 & 11 & 9.4 & 0 & 0.0 & 25 & 21.4 \\
\hline 3-5 million & 366 & 36 & 9.8 & 41 & 11.2 & 1 & 0.3 & 78 & 21.3 \\
\hline$>5$ million & 493 & 62 & 12.6 & 36 & 7.3 & 0 & 0.0 & 98 & 19.9 \\
\hline
\end{tabular}

${ }^{*}$ The proportion of the number of unintentional injuries to the overall number of each socioeconomic facto.

injuries was higher among preschool children with highschool graduate fathers and those in families with more siblings. However, there were no significant differences in incident rates of unintentional injuries across all groups. Table 4 shows the association between socioeconomic factors and timing of injury. Table 5 shows the association between socioeconomic factors and management after injury. Consistent with the main results, there was no relationship between socioeconomic factors and the variables in these tables.

The results of the multivariate analysis are shown in table 6. Between households reporting unintentional injuries and those that did not report any, no significant differences in terms of income of parents were observed in the incident rates of unintentional injuries among preschool children (adjusted OR 0.90; 95\% CI 0.53 to $1.53 ; \mathrm{p}=0.701$ ). Similarly, there were no significant differences in the other socioeconomic factors in terms of the incident rates of unintentional injuries among preschool children.

\section{DISCUSSION}

Herein, we observed that unintentional injuries among preschool children under 6 years old occurred at approximately constant rates and were unrelated to any socioeconomic factors in Japan. Socioeconomic disadvantages did not significantly increase the risk for unintentional injuries among preschool children.

Our data showed that households whose annual income was under 3 million yen accounted for $12.0 \%$ of the population, whereas the relative poverty rate for households with children was $12.9 \%$ in Japan. ${ }^{17}$ The incidence rate of unintentional injuries observed in our study is not very different from that reported in other studies: 29.0 injuries per 100 children over a period of 1 year within a population of 0-4-year-old children in a Greek town and 17.4 medically treated injuries within a population of 0-4-year-old children and adolescents in a health maintenance organisation. ${ }^{8} 19$

Nevertheless, our results differ from the outcomes reported in other studies of the relationship between unintentional injuries and socioeconomic factors. ${ }^{710} 12$ There are several explanations for these results. First, the younger age of children may affect the relationship between the risk for unintentional injuries and socioeconomic factors. A previous study showed very minor socioeconomic differences in the injury risk among 0-4-year-old children in Sweden. ${ }^{20}$ However, socioeconomic differences were observed for traffic injury risk from the age of 5 years onwards..$^{20}$ Another study reported that the relative risk of being injured in a road traffic incident is higher for 5-19-year-olds with low socioeconomic status than for those with higher socioeconomic status. ${ }^{21}$ Alternatively, caregiver supervision might modify the association between unintentional injury and socioeconomic factors in younger ages, because the proportion of injuries witnessed by caregivers was high in our study. A previous study suggested lack of supervision made children under 5 years at risk of high mortality by unintentional injuries. ${ }^{22}$ Therefore, the age of the children, which was under 6 years old in our study, might help to decrease the risk of unintentional injuries in lower socioeconomic status families. Second, the following characteristics specific to Japan might reduce the socioeconomic differences: relatively low exposure to environmental hazards, the social support network and ethnic homogeneity. ${ }^{23}$ The absolute number of traffic accidents in Japan has gradually decreased from 887000 in 2006 to 499000 in 2016, owing to new road traffic laws and improvements in the quality of roads, vehicle engineering and driver behaviour. ${ }^{24} 25$ The Japanese government provides households with children allowances according to income, employment or financial 
Table 6 Logistic regression models of socioeconomic indicators and unintentional injuries

\begin{tabular}{|c|c|c|}
\hline Factors & OR (95\% Cl) & $P$ values \\
\hline Family type & 0.60 (0.23 to 1.53$)$ & 0.283 \\
\hline Age of mother & & 0.433 \\
\hline$<29$ years & 1 (reference) & \\
\hline 30-39years & 0.68 (0.37 to 1.22$)$ & 0.196 \\
\hline$\geq 40$ years & 0.69 (0.34 to 1.37$)$ & 0.285 \\
\hline Age of father & & 0.849 \\
\hline$<29$ years & 1 (reference) & \\
\hline 30-39years & 1.23 (0.58 to 2.61$)$ & 0.596 \\
\hline$\geq 40$ years & 1.27 (0.56 to 2.85$)$ & 0.570 \\
\hline Education of mother & & 0.284 \\
\hline High school & 1 (reference) & \\
\hline $\begin{array}{l}\text { Business technical school } \\
\text { or junior college }\end{array}$ & 1.20 (0.82 to 1.82$)$ & 0.334 \\
\hline College & 0.90 (0.57 to 1.40$)$ & 0.629 \\
\hline Education of father & & 0.504 \\
\hline High school & 1 (reference) & \\
\hline $\begin{array}{l}\text { Business technical school } \\
\text { or junior college }\end{array}$ & 0.78 (0.47 to 1.29$)$ & 0.339 \\
\hline College & 0.81 (0.54 to 1.21$)$ & 0.299 \\
\hline Number of children & & 0.168 \\
\hline 1 & 1 (reference) & \\
\hline 2 & 1.51 (0.98 to 2.31$)$ & 0.059 \\
\hline$\geq 3$ & 1.49 (0.79 to 2.79$)$ & 0.215 \\
\hline Infant (<1 year old $)$ & 0.78 (0.49 to 1.23$)$ & 0.278 \\
\hline Older siblings (>6 years old) & 0.91 (0.58 to 1.43$)$ & 0.682 \\
\hline Living with grandmother & 0.87 (0.52 to 1.47$)$ & 0.606 \\
\hline Living with grandfather & $1.17(0.83$ to 1.65$)$ & 0.383 \\
\hline Mother's employment status & $0.99(0.67$ to 1.47$)$ & 0.976 \\
\hline Father's employment status & $0.79(0.20$ to 3.12$)$ & 0.737 \\
\hline $\begin{array}{l}\text { Use of sitter, kindergarten or } \\
\text { nursery school }\end{array}$ & 1.38 (0.88 to 2.16$)$ & 0.165 \\
\hline Type of housing & 0.97 (0.69 to 1.36$)$ & 0.836 \\
\hline Annual income (Yen) & & 0.849 \\
\hline$<3$ million & 1 (reference) & \\
\hline 3-5 million & 0.99 (0.58 to 1.69$)$ & 0.977 \\
\hline$>5$ million & 0.90 (0.53 to 1.53$)$ & 0.701 \\
\hline
\end{tabular}

support for single parent families, and visits for all families with infants. ${ }^{26}$ All municipalities in Japan conduct health checkups at healthcare centres for children aged 18-23 months and children aged 36-47 months, despite socioeconomic differences. The mean response rate for these health checkups is over $90 \%{ }^{27}$

Taken together, our data and those from previous studies confirm that the relationship between unintentional injury and socioeconomic factors differs for each nation. $^{6-8} 1011132829$ It is difficult to generalise the influence of socioeconomic factors on the risk of unintentional childhood injuries. Therefore, prevention strategies should vary from country to country. In Japan, prevention strategies that focus on socioeconomic disadvantages would be inadequate. A comprehensive approach that involves health checkups could be a useful method for prevention of unintentional injuries.

\section{Limitations}

This study had several limitations. First, only those households that had access to the internet were included. However, we selected households with a population distribution similar to that in the national census. We had a high internet penetration rate of the general population $(83.5 \%)$ in Japan. ${ }^{30}$ In addition, there were no differences between the relative poverty rates recorded in our study and those for the whole nation. Second, the outcome measures were based on self-reporting. The respondents may have been unaware of incidences of unintentional injury, or recalled the accident inaccurately. Thus, the incidence of unintentional injury might be underestimated. However, the incident rates recorded in our study are not very different from those obtained in other studies. Third, although we excluded households which had missing information regarding parent education and type of housing, this might have resulted in bias due to missing data. However, we excluded only 24 households. Additionally, the risk of unintentional injury was similar, despite of the high proportion of single parents in the missing data. Thus, it might not impact the validity of the conclusion. Finally, our inferences might be confounded by unmeasured factors, such as gender, mental health conditions and physical disability of the children. Future studies should measure the non-socioeconomic factors relating to unintentional injuries among children more explicitly.

\section{CONCLUSION}

Unintentional injuries among preschool children occurred at approximately constant rates irrespective of the presence of socioeconomic factors. The association between socioeconomic factors and unintentional injury varies across different countries. Prevention strategies aimed at unintentional injuries that take socioeconomic disadvantages into consideration may not be applicable in Japan.

Contributors NS conceived the study. YH, Jl and KA supervised the conduct of the trial and data collection. NS managed the data, including quality control. KA provided statistical advice on the study design and analysed the data; NS chaired the data oversight committee. NS, YH and KA drafted the manuscript, and all authors contributed substantially to its revision. NS takes responsibility for the paper as a whole. All authors read and approved the final manuscript.

Funding The authors have not declared a specific grant for this research from any funding agency in the public, commercial or not-for-profit sectors.

Competing interests None declared.

Patient consent Not required.

Ethics approval Niigata City General Hospital.

Provenance and peer review Not commissioned; externally peer reviewed. 
Data sharing statement The database set was available for all authors of the study, and will be available for other non-commercial researchers on request.

Open access This is an open access article distributed in accordance with the Creative Commons Attribution Non Commercial (CC BY-NC 4.0) license, which permits others to distribute, remix, adapt, build upon this work non-commercially, and license their derivative works on different terms, provided the original work is properly cited, appropriate credit is given, any changes made indicated, and the use is non-commercial. See: http://creativecommons.org/licenses/by-nc/4.0/.

\section{REFERENCES}

1. Alonge $\mathrm{O}$, Khan UR, Hyder AA. Our shrinking globe: implications for child unintentional injuries. Pediatr Clin North Am 2016;63:167-81.

2. Alonge $\mathrm{O}$, Hyder AA. Reducing the global burden of childhood unintentional injuries. Arch Dis Child 2014;99:62-9.

3. Hyder AA, Wali S, Fishman S, et al. The burden of unintentional injuries among the under-five population in South Asia. Acta Paediatr 2008;97:267-75.

4. Krug EG, Sharma GK, Lozano R. The global burden of injuries. Am J Public Health 2000;90:523-6.

5. Peden M, Oyegbite K, Ozanne-Smith J, et al. World Report on Child Injury Prevention. Geneva: World Health Organization, 2008.

6. Nathens AB, Neff MJ, Goss $\mathrm{CH}$, et al. Effect of an older sibling and birth interval on the risk of childhood injury. Inj Prev 2000;6:219-22.

7. Hjern A, Ringbäck-Weitoft G, Andersson R. Socio-demographic risk factors for home-type injuries in Swedish infants and toddlers. Acta Paediatr 2001;90:61-8.

8. Petridou E, Anastasiou A, Katsiardanis K, et al. A prospective population based study of childhood injuries: the Velestino town study. Eur J Public Health 2005;15:9-14.

9. Weitoft GR, Hjern A, Haglund B, et al. Mortality, severe morbidity, and injury in children living with single parents in Sweden: a populationbased study. Lancet 2003;361:289-95.

10. Laursen B, Nielsen JW. Influence of sociodemographic factors on the risk of unintentional childhood home injuries. Eur $\mathrm{J}$ Public Health 2008;18:366-70.

11. Faelker T, Pickett W, Brison RJ. Socioeconomic differences in childhood injury: a population based epidemiologic study in Ontario, Canada. Inj Prev 2000;6:203-8.

12. Laflamme $L$, Diderichsen $F$. Social differences in traffic injury risks in childhood and youth--a literature review and a research agenda. Inj Prev 2000;6:293-8.

13. de Lourdes Drachler M, de Carvalho Leite JC, Marshall T, et al. Effects of the home environment on unintentional domestic injuries and related health care attendance in infants. Acta Paediatr 2007;96:1169-73.
14. Sekii H, Ohtsu T, Shirasawa T, et al. Childhood mortality due to unintentional injuries in Japan, 2000-2009. Int J Environ Res Public Health 2013;10:528-40.

15. Director-General for statistics and information policy, Ministry of Health, Labour and Welfare. Vital statistics in Japan. Trends up to 2015. http://www.mhlw.go.jp/english/database/db-hw/dl/81-1a2en. pdf (accessed 20 Nov 2017).

16. OECD Rights and Translation Unit. Growing Unequal? Income Distribution and Poverty in OECD Countries. Paris: OECD publications, 2008

17. Ministry of Health, Labour and Welfare. Comprehensive Survey of Living Conditions of the People on Health and Welfare. Tokyo: Ministry of Health, Labour and Welfare, 2016.

18. Fujiwara T, Yamaoka Y, Morisaki N. Self-Reported Prevalence and Risk Factors for Shaking and Smothering Among Mothers of 4-Month-Old Infants in Japan. J Epidemiol 2016;26:4-13.

19. Rivara FP, Calonge N, Thompson RS. Population-based study of unintentional injury incidence and impact during childhood. Am J Public Health 1989;79:990-4.

20. Engström K, Diderichsen F, Laflamme L. Socioeconomic differences in injury risks in childhood and adolescence: a nation-wide study of intentional and unintentional injuries in Sweden. Inj Prev 2002;8:137-42.

21. Laflamme L, Engström K. Socioeconomic differences in Swedish children and adolescents injured in road traffic incidents: cross sectional study. BMJ 2002;324:396-7.

22. Khatlani $\mathrm{K}$, Alonge $\mathrm{O}$, Rahman $\mathrm{A}$, et al. Caregiver Supervision Practices and Risk of Childhood Unintentional Injury Mortality in Bangladesh. Int J Environ Res Public Health 2017;14:515.

23. Kagamimori S, Gaina A, Nasermoaddeli A. Socioeconomic status and health in the Japanese population. Soc Sci Med 2009;68:2152-60.

24. Nagata T, Setoguchi S, Hemenway D, et al. Effectiveness of a law to reduce alcohol-impaired driving in Japan. Inj Prev 2008:14:19-23.

25. National Police Agency. Trends in traffic accidents by year. Tokyo: Traffic accidents situation, 2016.

26. Ministry of Health, Labour and Welfare. Equal employment and child welfare. Tokyo: Ministry of Health, Labour and Welfare, 2015.

27. Yamamoto N, Honda C, Nagata S. Current trends and age-based differences of unintentional injury in Japanese children. Biosci Trends 2016;10:152-7.

28. Chowdhury AH, Hanifi SMA, Mia MN, et al. Socioeconomic inequalities in under-five mortality in rural Bangladesh: evidence from seven national surveys spreading over 20 years. Int $J$ Equity Health 2017:16:197.

29. Fang $X$, Jing $R$, Zeng $G$, et al. Socioeconomic status and the incidence of child injuries in China. Soc Sci Med 2014;102:33-40.

30. Ministry of Internal Affairs and Communications. Information and Communications in Japan 2017. Tokyo: Ministry of Internal Affairs and Communications, 2017. 